\title{
Cobalt hyperaccumulation in Rinorea cf. bengalensis (Violaceae) from Sabah: accumulation potential and tissue and cellular-level distribution of cobalt
}

\author{
Adrian L. D. Paul, Philip Nti Nkrumah, Guillaume Echevarria, Peter D. Erskine, \\ Rufus L. Chaney, Kathryn M. Spiers, Sukaibin Sumail, Antony van der Ent \\ Centre for Mined Land Rehabilitation, Sustainable Minerals Institute, The University of \\ Queensland, Brisbane, Queensland, Australia \\ Laboratoire Sols et Environnement, UMR 1120, Université de Lorraine-INRAE, Vandouvre- \\ lès-Nancy, Grand Est, France \\ Chaney Environmental, Beltsville, Maryland, USA \\ Photon Science, Deutsches Elektronen-Synchrotron DESY, Hamburg, Germany \\ Sabah Parks, Herbarium, Kota Kinabalu, Sabah, Malaysia
}




\begin{abstract}
Aims Knowledge on the ecophysiology of cobalt hyperaccumulator species is limited. The nickel hyperaccumulator Rinorea cf. bengalensis from Borneo can accumulate high concentrations of cobalt in nature. This study investigates the cobalt accumulation potential of Rinorea cf. bengalensis in relation to nickel concentrations in soils and the subsequent tissue and cellular-level distributions of cobalt, nickel, and major cations.

Methods Seedlings of Rinorea cf. bengalensis were grown in mixed treatments on ultramafic soil containing a high concentration of available nickel. Cobalt and nickel salts were then added to the soil to study their interactions. The tissue and cellular-level distributions of cobalt, calcium, nickel, and potassium were investigated using synchrotron-based X-ray fluorescence microscopy.

Results The maximum foliar cobalt concentration reached $1200 \mu \mathrm{g} \mathrm{g}^{-1}$. Accumulation of cobalt competed with nickel accumulation although nickel seems to stimulate cobalt phloem translocation. Plants suffered toxicity in the treatment with the highest soil cobalt concentration. Cobalt and nickel have contrasting distribution patterns in the leaves of Rinorea cf. bengalensis, with cobalt mainly excreted on the surface of the leaves, whereas nickel is localised in foliar epidermal cells.

Conclusions Rinorea cf. bengalensis can accumulate high concentrations of cobalt but is intrinsically more tolerant to nickel. It does not rely on a similar sequestration mechanism for both metals, which could explain the lesser tolerance for cobalt. Nickel appears to be essential for the plant to tolerate high cobalt concentrations. Further studies intending to develop agronomic practices are needed to determine the viability of

Rinorea $\mathrm{cf}$. bengalensis for nickel-cobalt agromining.
\end{abstract}

\title{
Keywords
}

Cobalt, Distribution, Hyperaccumulator, Toxicity, Rinorea cf. bengalensis, Synchrotron 


\section{INTRODUCTION}

Metal hyperaccumulating plants can uptake and store extraordinary concentrations of metals and metalloids in their living tissues that may be two or three orders of magnitude higher than normal plants (Baker and Brooks 1989; van der Ent et al. 2013). Only a minority of plants are defined as metal or metalloid hyperaccumulators as only $\sim 700$ species scattered in $\sim 50$ families have been reported to date ( $\sim 0.2 \%$ of flowering plants) (Reeves et al. 2018$)$. The majority $(\sim 70 \%)$ of these species hyperaccumulate nickel (Ni) and thrive in soils that formed from the weathering of ultramafic bedrock. These soils are naturally enriched in cobalt $(\mathrm{Co})$, chromium $(\mathrm{Cr})$, manganese $(\mathrm{Mn})$ and $\mathrm{Ni}$, are deficient in major macronutrients (phosphorus $(\mathrm{P})$ and potassium $(\mathrm{K})$ ) and have a low calcium $(\mathrm{Ca})$ to magnesium $(\mathrm{Mg})$ molar ratios (van der Ent et al. 2015a). These soils are rather widely distributed on Earth (3\% of its surface) and cover large areas in some territories (e.g., Cuba, New Caledonia, Malaysia, Indonesia) (Guillot and Hattori 2013; Proctor 2003). Several hypotheses have been proposed as potential ecological drivers that led to the appearance of hyperaccumulation independently in multiple different plant families, even though its physiological cost is presumably considerable, and include increased drought tolerant or metal disposal/tolerance functions (Boyd and Martens 1992). Litter decay enriches the local ecosystem in $\mathrm{Ni}$ and may lead to allelopathic effects (i.e., competitive interference) through litterfall (van der Ent et al. 2015b). The most broadly accepted hypothesis for the evolution of Ni hyperaccumulation is known as "elemental defence" which supports the idea that hyperaccumulation fulfils herbivory protection functions (Boyd 2007; Hörger et al. 2013).

The Violaceae is a cosmopolitan family of subshrubs, shrubs and trees with $\sim 800$ accepted species in 25 genera. The principal genera are Viola, a genus found in temperate and mountainous regions ( $\sim 75$ spp.), Rinorea ( 160 spp.) and Hybanthus ( $\sim 70$ spp.) both the latter being pantropical (Ballard et al. 2014; Wahlert and Ballard 2012). In Malesia, 11 species occur, among which eight on the island of Borneo (Wahlert and Ballard 2012). Rinorea cf. bengalensis (Violaceae) is commonly found all over Southeast Asia, and its range extends from India to North-Queensland. It is a facultative species that grows on both non-ultramafic and ultramafic soils, and a facultative hyperaccumulator as only the ultramafic populations have high foliar Ni concentrations (Brooks et al. 1977; Brooks and Wither 1977). In Sabah (Malaysia, on the island of Borneo), local populations grow on circum-neutral ultramafic soils with relatively high phytoavailable Ni concentrations (Nkrumah et al. 2018b). Trees from these populations may reach $25 \mathrm{~m}$ high and have highly Ni-enriched phloem tissues and leaves with concentrations reaching up 22,600 and $12,800 \mu \mathrm{g} \mathrm{g}^{-1}$ d.w. respectively (van der Ent and Mulligan 2015; van der Ent et al. 2017). The Ni- rich green-coloured phloem tissues observed in $R$. cf. bengalensis appear to be a common feature of tropical woody Ni hyperaccumulator plants and hint at the critical role of the phloem in redistributing Ni to other plant tissues in this species (van der Ent et al. 2020a). So far, it has been documented eight times, mostly in Ni hyperaccumulator species from Southeast Asia (Nkrumah et al. 2018b). Two other species from the Violaceae family exhibit this atypical phloem (Hybanthus austrocaledonicus from New Caledonia and Rinorea cf. javanica endemic to Southeast Asia). Four other species are Dichapetalum gelonioides subsp. tuberculatum (Dichapetalaceae) and Actephila alanbakeri, Phyllanthus rufuschaneyi, and Phyllanthus balgooyi (Phyllanthaceae) which are all from the 
Indomalaya realm and in the COM (Celastrales, Oxalidales and Malpighiales) clade (Bouman et al. 2018; Nkrumah et al. 2018a; van der Ent et al. 2015a, b, 2016, 2017). The most recently discovered Blepharidium guatemalense (Rubiaceae) from Mexico also has the same adaptations, with a bright green phloem tissue containing more than 50,000 $\mu \mathrm{g} \mathrm{g}^{-1} \mathrm{Ni}$ d.w. and was the first to be discovered outside the Asia-Pacific Region (unpublished data).

Rinorea cf. bengalensis, a long-lived large tree with a well-developed phloem, is an ideal model for studying hyperaccumulation and phloem translocation (van der Ent et al. 2017). It is also a fast-growing species which is ostensibly competitive in its natural habitat especially in early succession after disturbance (it is one of the most common/dominant trees on ultramafic soils in Sabah). Hence, any metabolic cost of Ni hyperaccumulation in $R$. cf. bengalensis does not come at a competitive disadvantage. However, the acquisition, transport, and complexation of Ni using substantial amounts of chelators (e.g., citrate, malate) must come at a significant metabolic cost for $R$. cf. bengalensis (van der Ent et al. 2017). This argues for a beneficial role of hyperaccumulation on either growth rate (i.e., competitive advantage due to less insect damage) or survival (i.e., of the seedlings due to allelopathic effects on other plants). The extremely high concentrations of $\mathrm{Ni}$ in the phloem combined with the current evidence for repeated $\mathrm{Ni}$ translocation ( $\mathrm{Ni}$ is translocated to young leaves and then pumped through the phloem to older leaves) in $R$. cf. bengalensis trees (Zelano et al. 2020), suggests that a yet to be identified (physiological) function could be important to plant fitness in $R$. cf. bengalensis. Comparable to most other $\mathrm{Ni}$ hyperaccumulator species, $\mathrm{Ni}$ is sequestered in the epidermal cells of $R$. cf. bengalensis (van der Ent et al. 2017). The vacuoles of the foliar epidermal cells, by virtue of their distance from the photosynthetic processes occuring in the mesophyll, are key in sequestrating $\mathrm{Ni}$ in leaves of many hyperaccumulating taxa (Küpper et al. 2001).

Although Co is critical for rhizobia associated with legumes in nitrogen-fixation, it is not essential for plants, nor does it take part in any metabolic processes in higher plants (De Hertogh et al. 1964). In contrast, $\mathrm{Ni}$ is essential for nitrogen assimilation as part of the enzyme urease (Dixon et al. 1975). In excess, Co disrupts photosynthesis and induces iron (Fe) deficiency and the production of reactive oxidative species which ultimately lead to leaf chlorosis and a growth rate reduction (Chen et al. 2009; Morrissey et al. 2009). Hyperaccumulation of $\mathrm{Co}$ is globally rare ( $\sim 40$ species) and is mostly reported in $\mathrm{Cu}-\mathrm{Co}$ outcrops of the Copperbelt divided between the Democratic Republic of Congo and Zambia in Central Africa (Lange et al. 2017). In the African Co hyperaccumulator Haumaniastrum katangense (Lamiaceae), Co is complexed with carboxylic acids, while in Persicaria punctata (Polygonaceae) Co is mainly distributed in epidermal cells and the phloem (van der Ent et al. 2019, 2020b). The Co coordination chemistry has an aqueous Co (II)-tartrate complex that is the predominant component identified in all plants and tissues, along with a minor component of a Co (III) compound with oxygen donor ligands (van der Ent et al. 2020b). Cobalt promotes growth and appears to be essential in the hyperaccumulator species Haumaniastrum robertii, where it is mainly localised in vascular bundles of roots and leaves (Kabeya et al. 2018). Experimental work with Crotalaria cobalticola (Fabaceae) has shown significant increases of citric acid and cysteine when plants are exposed to Co, whereas phytochelatin synthesis was not induced (Oven et al. 2002). It has been hypothesised that Co hyperaccumulation has 
evolved from adaptations in Fe homeostasis (Lange et al. 2017). Very little is known about the ecophysiology of $\mathrm{Co}$ in tropical woody hyperaccumulator plants. Micro-analytical investigations on Glochidion cf. sericeum (Phyllanthaceae) from Sabah (Malaysia), a small tree which accumulates up to $1500 \mu \mathrm{g} \mathrm{g}^{-1} \mathrm{~d}$.w., have shown that Co is localised in lesions on the leaf surface and complexed with carboxylic acids (van der Ent et al. 2018).

Phytomining (also called agromining) is a type of agriculture in which hyperaccumulator species are cultivated on metalliferous soils (sub-economic mineralisation and contamination by industry) and their biomass harvested to extract valuable metals such as Co or Ni (Chaney et al. 2014; van der Ent et al. 2015c). Nickel phytomining may become transformative in the rehabilitation of Ni strip-mining operations in Southeast Asia where very extensive ultramafic outcrops exist (van der Ent et al. 2015a). Cobalt phytomining may extract resources that are not readily extractable with conventional mining/metallurgical processes (Lange et al. 2017). Greenhouse and field trials in Sabah intending to develop the agronomy of several tropical $\mathrm{Ni}$ hyperaccumulator species have highlighted the potential of $R$. cf. bengalensis to be used in $\mathrm{Ni}$ phytomining operations owing to its rapid growth and extraordinary levels of Ni accumulation (Nkrumah et al. 2018b; van der Ent et al. 2015b). Further studies have shown that Ni uptake and plant growth were species-dependent when exposed to different formulations of standard inorganic fertilisers (N, P and K) or other amendments (Ca, S and organic matter) (Nkrumah et al. 2019a, b).

Two Rinorea species from Southeast Asia have been reported to hyperaccumulate Co $(>300$ $\mu \mathrm{g} \mathrm{g}^{-1}$ d.w., the hyperaccumulation threshold), with concentrations up to $670 \mu \mathrm{g} \mathrm{g}^{-1} \mathrm{~d}$.w. in $R$. cf. javanica and up to $545 \mu \mathrm{g} \mathrm{g}^{-1} \mathrm{~d}$.w. in $R$. cf. bengalensis in their natural habitat (Brooks et al. 1977; Brooks and Wither 1977; Lange et al. 2017; Reeves et al. 2018). A better understanding of the ecophysiology of $R$. cf. bengalensis is crucial to developing effective Co, and $\mathrm{Ni}$ agromining as the commercial viability depends on the combination of biomass production per time unit and $\mathrm{Co} / \mathrm{Ni}$ accumulation in the crop.

Previous synchrotron and nuclear microprobe investigations have revealed very high levels of accumulation in the phloem bundles of the roots and stems (van der Ent et al. 2017). In the leaves, Ni is preferentially accumulated in the epidermal cell region (van der Ent et al. 2020a). The chemical form of $\mathrm{Ni}^{2+}$ does not substantially differ and is unambiguously associated with citrate in Rinorea (van der Ent et al. 2017). No information is presently available about the tissue-level distribution of Co in $R$. cf. bengalensis plants exposed to high soil Co. Rinorea $\mathrm{cf}$. bengalensis has the potential to hyperaccumulate Co and may be used for future sustainable phytomining applications. This study aimed at better understanding the trade-offs between Co and $\mathrm{Ni}$ accumulation in $R$. cf. bengalensis by undertaking a $\mathrm{Co}$ and $\mathrm{Ni}$ soil dosing pot experiment. In order to establish if both elements could be accumulated through the same uptake and translocation pathways, micro-analytical techniques based on synchrotron X- ray fluorescence microscopy on live plants were used to elucidate the distribution of Co and other physiologically relevant elements at the tissue and cellular levels. This information will ultimately be useful to develop methods to increase Co accumulation in $R$. cf. bengalensis for phytomining applications. 


\section{MATERIALS AND METHODS}

\section{Plant stock source}

Rinorea $\mathrm{cf}$. bengalensis wildlings ( $\sim 15 \mathrm{~cm}$ height) were collected from their native habitat (345 m a.s.1.; $6^{\circ} 12^{\prime} 2^{\prime \prime} \mathrm{N} ; 116^{\circ} 45^{\prime} 8^{\prime \prime} \mathrm{E}$ ). All wildlings were potted immediately after collection with soil collected from the native habitat and allowed to acclimatise in a shade house for 2 weeks. The wildlings were then transplanted into test pots $(8 \mathrm{~L}$ with $10 \mathrm{~kg}$ ultramafic soil) and allowed to establish for 3 months. The soil originated from the top 15-20 cm of an unfertilised ultramafic soil (Eutric Cambisol Magnesic) near Pahu village, Sabah, Malaysia (6 $6^{\circ} 49^{\prime} \mathrm{N}$; $116^{\circ} 46^{\prime} 22^{\prime \prime} \mathrm{E}$ ) and it is roughly the same type of soil on which the wildlings were collected. The soil was sun-dried, sieved through a $1-\mathrm{cm}$ stainless steel screen, homogenised, and analysed (Table 1). The initial Ni:Co pseudo total concentration ratio was approximatively 10 with concentrations of $\mathrm{Ni}$ and $\mathrm{Co}$ of 4730 and $445 \mathrm{mg} \mathrm{kg}^{-1}$ respectively.

\section{Plant culture conditions}

The experiment was conducted in a shade-house covered with neutral-density shade-cloth at the Monggis sub-station in Sabah, Malaysia $\left(6^{\circ} 11^{\prime} 59.7^{\prime \prime} \mathrm{N} 116^{\circ} 45^{\prime} 08.0^{\prime \prime} \mathrm{E}\right)$. The climate at the sub- station is tropical with a daytime temperature of $29{ }^{\circ} \mathrm{C}$ and an average relative humidity of $75 \%$. Transparent polyethene film roofing was used to maintain the light intensity uniform in the shade house and keep rainfall out to better control plant irrigation. The light intensity under the shade house was $350 \mu \mathrm{mol} \mathrm{m} \mathrm{sec}^{-1}$ Photosynthetically active radiation (PAR) light (measured with an Apogee MQ-500 spectroradiometer) to favour the growth of understorey species. The plants were watered daily to field capacity with local water tapped from a nearby river to mimic the conditions in the native environment. As the river originates from an intact lowland rain forest in sandstone soils, water concentrations of $\mathrm{Ni}$ and Co were low $(<0.01 \mathrm{mg}$ $\mathrm{L}^{-1}$ ) while variations expected to be minimal during the experiment (constant flow rate supplied from the water table). Plants were harvested after a 12-month growth period during which they were separated into fine root, taproot, old stem, young stem, old leaf and young leaf fractions. The roots were thoroughly washed with water to remove soil particles to reduce surficial contamination.

\section{Plant dosing treatments}

Soils were amended with $\mathrm{Ni}$ and $\mathrm{Co}$ in the form of the nitrate salts $\mathrm{Ni}\left(\mathrm{NO}_{3}\right)_{2} \bullet 6 \mathrm{H}_{2} \mathrm{O}$ and $\mathrm{Co}\left(\mathrm{NO}_{3}\right)_{2} \cdot 6 \mathrm{H} 2 \mathrm{O}$ in solutions to $10 \mathrm{~kg}$ dry soil pots containing previously watered soil. In this study, three different modalities which aimed to increase pseudo-total concentrations of Co or $\mathrm{Ni}$ by a $\sim 1 / 3$ ratio and a control were used: Ni100Co1500 $\left(+100 \mathrm{mg} \mathrm{kg}^{-1} \mathrm{Ni} /+1500 \mathrm{mg} \mathrm{kg}^{-1}\right.$ Co), Ni750Co750 (+750 mg kg-1 $\left.\mathrm{Ni} /+750 \mathrm{mg} \mathrm{kg}^{-1} \mathrm{Co}\right), \mathrm{Ni} 1500 \mathrm{Co} 100$ (+1500 mg kg-1 $\mathrm{Ni} /$ $+100 \mathrm{mg} \mathrm{kg}^{-1} \mathrm{Co}$ ) and control ( $\left.+0 \mathrm{mg} \mathrm{kg}^{-1} \mathrm{Ni} /+0 \mathrm{mg} \mathrm{kg}^{-1} \mathrm{Co}\right)$. Following the amendments, the soil in each pot was thoroughly mixed, sun-dried, homogenised, watered to reach field capacity and equilibrated for 10 days before transplanting. Pots were arranged in a randomised complete block design with three replications for each Ni:Co combination treatment. The pots were randomised regularly to limit differences caused by light or humidity heterogeneity in the shade house. 


\section{Chemical analysis of soil and plant material samples}

Soil $\mathrm{pH}$ was determined by shaking for $2 \mathrm{~h}$ a 1 to 2.5 soil to water mixture. The $\operatorname{Sr}\left(\mathrm{NO}_{3}\right)_{2}-$ extraction $(0.01 \mathrm{M})$ evaluated the soil solution concentrations of trace elements: $5 \mathrm{~g}$ soil to 20 $\mathrm{mL}$ extractant ratio and a $2 \mathrm{~h}$ shaking time. Cation exchange capacities (CEC) of the soil $(\sim 700$ $\mathrm{mg}$ ) was determined by measuring the silver remaining in solution after adding $40 \mathrm{ml}$ of a 0.01 $\mathrm{M}$ silver-thiourea solution and shaking for $16 \mathrm{~h}$. Phytoavailable concentrations were assessed with the diethylenetriaminepentaacetic acid (DTPA) extraction modified by using $5 \mathrm{~g}: 20 \mathrm{~mL}$ (soil:solution ratio). Soil samples $(\sim 100 \mathrm{mg})$ were digested with $9 \mathrm{~mL} 70 \% \mathrm{HNO}_{3}$ and $3 \mathrm{~mL}$ $37 \% \mathrm{HCl}$ per sample in a microwave (Milestone Start One) for $1.5 \mathrm{~h}$ and diluted with ultrapure water before analysis to determine pseudo-total elemental concentrations. All digests and extracts were analysed by inductively coupled plasma atomic emission spectroscopy (ICPAES - PerkinElmer Optima 8300) for aluminium (Al), Ca, Co, Cr, copper (Cu), Fe, K, Mg, $\mathrm{Mn}, \mathrm{Ni}, \mathrm{P}$, sulphur (S), and zinc (Zn). In-line internal addition standardisation using yttrium was used to compensate for matrix-based interferences. The plant material was oven-dried at $65^{\circ} \mathrm{C}$ for 2 days, weighed and ground in a stainless-steel ball mill. Sub-samples $(\sim 300 \mathrm{mg})$

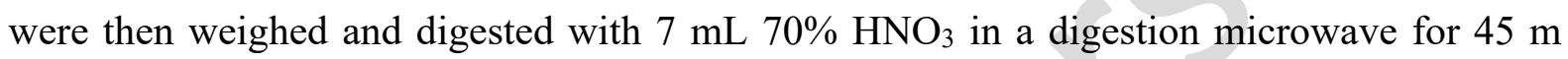
(Milestone Start D) and diluted with ultrapure water (Millipore $18.2 \mathrm{M} \Omega \cdot \mathrm{cm}$ at $25^{\circ} \mathrm{C}$ ) to 40 $\mathrm{mL}$ before analysis using an ICP-AES (PerkinElmer Optima 8300). National Institute of Standards and Technology apple leaf standard reference material (\#1515) and internal standards were analysed for quality assurance.

\section{X-ray fluorescence microscopy (XFM)}

Full leaves, which were alive, were mapped for the study of elemental micro-localisation using XFM techniques. The XFM experiment was undertaken at PETRA III (Deutsches ElektronenSynchrotron) a $6 \mathrm{GeV}$ synchrotron. The microprobe beamline P06 is equipped with a cryogenically cooled double-crystal monochromator with $\mathrm{Si}(111)$ crystals and a $\mathrm{K} / \mathrm{B}$ mirror which focusses a beam of 1011 photon/s down to $300 \mathrm{~nm}$ size in the energy range 5-21 keV (Schroer et al. 2010). The Maia detector uses a large detector array to maximise detected signal and count-rates, enabling high overall count-rates (Kirkham et al. 2010; Siddons et al. 2014). It enables a large solid angle ( $1.2 \mathrm{sr})$ to be achieved in order to either maximise detected signal or reduce the dose and potential damage to a specimen (Ryan et al. 2010). Maia is designed for event-mode data acquisition, where each detected X-ray event is recorded, tagged by detector number in the array, position in the scan and other metadata (Ryan et al. 2014).

The possibility of radiation-induced damage in XFM analysis (especially in hydrated plant tissue samples) is an important consideration that may limit the information sought from the analysis (van der Ent et al. 2018). In a recent study, radiation dose limits for XFM analysis were assessed, and in hydrated plant tissue dose-limits are $4.1 \mathrm{kGy}$ before detectable damage occurs (Jones et al. 2020). In order to limit radiation damage, we use fast scanning by limiting per-pixel dwell time to $<10 \mathrm{~ms}$. Cross-sections were hand-cut with a stainless-steel razor blade ("dry knife" method); whole or sectioned samples were then mounted between two sheets of 4 $\mu \mathrm{m}$ Ultralene thin film in a tight sandwich to limit evaporation and were analysed within 10 min after excision. The X-ray fluorescence event stream was analysed using the Dynamic Analysis method (Ryan 2000; Ryan and Jamieson 1993) as implemented in GeoPIXE (Ryan 
et al. 1990, 2005). The matrix file used for the spectra fitting was an assumed plant material composition of $\mathrm{C} 7.3 \mathrm{O} 33 \mathrm{H} 59 \mathrm{~N} 0.7 \mathrm{~S} 0.8$ with a density of $0.90 \mathrm{~g} \mathrm{~cm}^{-3}$ and considered the two layers of Ultralene $(4 \mu \mathrm{m})$.

\section{Histochemistry and bright field microscopy of plant tissues}

Tissue samples were fixed in 3\% glutaraldehyde (in PBS), sectioned with a vibratome (Leica VT1000s) and stained with Toluidine Blue. The sections (20-40 $\mu \mathrm{m}$ thickness) were then examined and photographed with a bright field microscope (Aperio XT Slide Scanner).

\section{Statistical analyses}

Statistical analyses were conducted with the RStudio software, version 3.6 .3 (2020-02-29). When the data followed a normal distribution (Shapiro test) and were homoscedastic (Levene test), a parametric test (Waller- Duncan K-ratio t-test) was applied. If the data did not meet both criteria, they were transformed to log values in order to meet the conditions of application for the parametric tests. The $\alpha$ level was set at 0.05 for each statistical evaluation.

\section{RESULTS}

\section{Nickel-cobalt dose responses in plant organs/tissues}

Initially, in the control soil, the phytoavailable $\mathrm{Ni} / \mathrm{Co}$ quotient was 23 in the $\operatorname{Sr}\left(\mathrm{NO}_{3}\right)_{2}$ extract and 14 in the DTPA extract (Table 1). Plants grew well on all soil treatments, and no clear biomass difference between treatments was observable. However, old leaves from both Ni1500Co100 and Ni100Co1500 treatments developed chlorosis (more intense in the higher Co-treatment) that started in the second half of the trial while plants from the Ni750Co750 treatment were visually healthy at harvest (Fig. 1). The concentrations of Co and $\mathrm{Ni}$ in $R$. cf. bengalensis plant parts are given in Figs. 2 and 3. Other relevant elements are shown in the Table S1. Nickel accumulation in the young leaves was similar to control for all three treatments. Thus, the Ni mean concentrations ranged from 800 to $1300 \mu \mathrm{g} \mathrm{g}^{-1} \mathrm{~d}$.w. in young leaves. In contrast, differences between treatments in old leaves were major as Ni mean concentration reached $4590 \mu \mathrm{g} \mathrm{g}^{-1} \mathrm{~d}$.w. in Ni100Co1500, twice as high as concentrations found in Ni1500Co100 and the control at $\sim 2500 \mu \mathrm{g} \mathrm{g} \mathrm{g}^{-1} \mathrm{~d}$.w. (but no statistically significant differences) and four times more than in Ni750Co750 (1130 $\mathrm{g} \mathrm{g}^{-1}$ - significantly different). Soil amendments had a substantial influence on plant Co uptake and accumulation in leaves. Cobalt concentrations in all plant organs were significantly higher in Ni100Co1500 soils compared to all other treatments except for old leaves. Indeed, the old leaves of the plants growing in Ni750Co750 pots had the highest mean Co concentrations with $1250 \mu \mathrm{g} \mathrm{g}^{-1} \mathrm{~d}$.w. in comparison to $626 \mu \mathrm{g} \mathrm{g}^{-1} \mathrm{~d}$.w. in Ni100Co1500, $447 \mu \mathrm{g} \mathrm{g}^{-1} \mathrm{~d}$.w. in Ni1500Co100 and $16.1 \mu \mathrm{g}$ $\mathrm{g}^{-1} \mathrm{~d}$.w. in the control treatment. Young leaves had approximatively $1000 \mu \mathrm{g} \mathrm{g}^{-1} \mathrm{~d}$.w. of Co for Ni100Co1500 and similarly around $220 \mu \mathrm{g} \mathrm{g}^{-1} \mathrm{~d}$.w. for both Ni1500Co100 and Ni750Co750 pots. Concentrations of $\mathrm{Mg}, \mathrm{Mn}, \mathrm{P}$ in organs varied following soil $\mathrm{Co}$ and $\mathrm{Ni}$ amendments. Relatively lower P and Mn concentrations occur in both Ni1500Co100 and Ni100Co1500, compared to that in the control. In contrast, $\mathrm{Mg}$ was significantly higher in the Ni100Co1500 treatment. The concentrations of $\mathrm{Al}, \mathrm{Cr}$, Fe were unremarkable in the above-ground parts and rather high in the below-ground parts (roots) where the risk of contamination by soil particles 
is known to be high. As to tissue $\mathrm{Cu}$ and $\mathrm{Zn}$ concentrations, no particular trends were observed, and the concentrations were low.

\section{Elemental distribution of relevant elements in Rinorea cf. bengalensis leaves}

Micro X-ray fluorescence ( $\mu \mathrm{XRF}$ ) images of a young leaf and of an old leaf from a plant growing in the equimolar Ni750Co750 treatment are shown in Figs. 4 and 5. Potassium was predominantly found in the midrib of both young and old leaves $(>1 \mathrm{Wt} \%)$, but the lateral veins and tissues surrounding the midrib were enriched as well. The concentrations of $\mathrm{K}$ in veinlets distinguished old to young leaves as $\mathrm{K}$ concentration was lower in the veinlets of young leaves $(<0.5 \mathrm{Wt} \%)$ compared to old leaves $(>0.6 \mathrm{Wt} \%)$. Additionally, serrated foliar margins were poor in $\mathrm{K}$ while the surrounding tissues were enriched. In the same manner, tissues adjacent to the midrib were also enriched. In contrast to $\mathrm{K}$ distribution, $\mathrm{Ca}$ distribution changed substantially during leaf ageing. In young leaves, midrib and secondary veins were depleted of $\mathrm{Ca}(<0.5 \mathrm{Wt} \%)$ while veinlets were, on the contrary, enriched $(>1.0 \mathrm{Wt} \%)$. In old leaves, $\mathrm{Ca}$ distribution was almost exclusively located in the vein network. In the young leaves, the range of Co concentrations was somewhat limited (200-400 $\left.\mu \mathrm{g} \mathrm{g}^{-1}\right)$ with a relatively homogeneous distribution, but a depletion in the tissues adjacent to the midrib and the veinlets $\left(\sim 100 \mu \mathrm{g} \mathrm{g}^{-1}\right)$. In the old leaves, concentrations between leaf parts were highly heterogeneous as the whole vein system was enriched in Co $\left(\sim 2000 \mu \mathrm{g} \mathrm{g}^{-1}\right)$ whereas the lamina had a markedly lower concentration $\left(\sim 1000 \mu \mathrm{g} \mathrm{g}^{-1}\right)$. The highest concentration of Co was observed in the teeth located at the margin of the leaves with a clear enrichment of the surrounding tissues. Additionally, precipitations were located randomly on the entire leaf surface and displayed very high concentrations of not only Co but also Ni. In young leaves, Ni mirrored Co distribution but with stricter delimitations. The midrib and lamina had the highest Ni concentrations (300-400 $\mu \mathrm{g} \mathrm{g}^{-1}$ ) while the lowest concentrations were found in the tissues adjacent to the midrib and in the veinlets where Ni depletion was more pronounced than Co $\left(100 \mu \mathrm{g} \mathrm{g}^{-1}\right)$. In old leaves, aside from the midrib that had the highest Ni concentration in the leaf $\left(800 \mu \mathrm{g} \mathrm{g}^{-1}\right)$, the concentration of $\mathrm{Ni}$ was rather homogeneous $\left(500 \mu \mathrm{g} \mathrm{g}^{-1}\right)$ with $\mathrm{Ni}$ being predominantly located in the vein network.

\section{Elemental distribution in cross-sections of leaves and petioles}

Different tissues could be distinguished within the leaves and petioles under the light microscope (Fig. 6). $\mu \mathrm{XRF}$ images of the midrib, the petiole and the leaf cross-section of an old leaf of a plant growing in the Ni750Co750 treatment are shown in Figs. 7, 8 and 9.

Midrib area - Potassium was localised in the cortex and also noticeably present at lower concentrations, in the lower and upper epidermis while the vascular bundle was relatively depleted in $\mathrm{K}$. The phloem was depleted in Ca whereas xylem had hotspots with remarkable concentrations ( $>3 \mathrm{Wt} \%$ ) while $\sim 0.5 \mathrm{Wt} \%$ was found on average in the apoplast. Nevertheless, the highest concentration of $\mathrm{Ca}$ was found in the sclerenchyma $(3 \mathrm{Wt} \%)$ and at a lower extent in the leaf blade epidermis and the adaxial part of the midrib epidermis $(>1.5 \mathrm{Wt} \%)$. Similarly, as in many other Ni hyperaccumulator plant species, Ni was preferentially accumulated in the foliar epidermal cells where it was almost exclusively localised in the upper epidermis of the leaves (midrib and blade) and the blade lower epidermis $\left(>2500 \mu \mathrm{g} \mathrm{g}^{-1}\right)$. The phloem and xylem 
tissues were depleted in $\mathrm{Ni}$, similarly to what was observed with $\mathrm{K}$. Although Co was not segregated to one tissue, contrary to $\mathrm{Ni}$, it was not homogeneously distributed within the leaf. The highest concentrations were found in the lower and upper epidermis, including in the midrib area and in the sclerenchyma $\left(\geq 1000 \mu \mathrm{g} \mathrm{g}^{-1}\right)$. High concentrations were also found in the apoplast located in the direct vicinity of the lower epidermis $\left(>600 \mu \mathrm{g} \mathrm{g}^{-1}\right)$.

Petiole - The $\mu \mathrm{XRF}$ imaging shows that $\mathrm{K}$ distribution is rather homogeneous. However, lower concentrations were found in the bottom area of the petiole, while the xylem was distinctly depleted of $\mathrm{K}$. On the contrary, the epidermis had the highest $\mathrm{K}$ concentrations $(2 \mathrm{Wt} \%)$. Calcium had a particular enrichment pattern with high $\mathrm{Ca}$ hotspots found in the xylem, sclerenchyma and parenchyma $(>5 \mathrm{Wt} \%)$ and relatively low enrichment in the epidermis $(<3$ $\mathrm{Wt} \%$ ). Although $\mathrm{Co}$ and $\mathrm{Ni}$ had a similar pattern with high concentrations in the collenchyma and sclerenchyma ( $>500 \mu \mathrm{g} \mathrm{g}^{-1} \mathrm{~d}$.w. and $1500 \mu \mathrm{g} \mathrm{g}^{-1} \mathrm{~d}$.w., respectively), a difference existed in that $\mathrm{Ni}$ appeared to be localised in the inner part of collenchyma cells while Co was located in the apoplast. Cobalt and $\mathrm{Ni}$ also had some enrichment in the apoplast of xylem, but it did not exceed concentrations found in other enriched tissues $\left(\sim 400 \mu \mathrm{g} \mathrm{g}^{-1} \mathrm{~d}\right.$.w. for Co and $1000 \mu \mathrm{g} \mathrm{g}^{-}$ ${ }^{1}$ d.w. for Ni). In the epidermis, both $\mathrm{Co}$ and $\mathrm{Ni}$ had moderate to low enrichment.

Leaf cross-section - Only the upper and lower epidermis were enriched in $\mathrm{Ni}$ (concentrations attained $1000 \mu \mathrm{g} g-1)$ with no real difference be- tween them. No Ni enrichment was observed in the vascular bundles. Cobalt shared the same pattern with a substantial enrichment of the upper epidermis and, to a lesser degree, the lower epidermis. In both mesophyll tissues and vascular bundles, Co concentrations were low. Calcium and $\mathrm{K}$ mirrored $\mathrm{Co}$ and Ni distribution as both epidermal regions were substantially enriched. However, $\mathrm{Ca}$ distinguished itself from other elements as a striking contrast between the epidermis and other tissues was observed. Calcium concentrations were extremely high in both epidermal layers when located close to the vascular bundles, but below the detection limits in the palisade and spongy mesophylls.

\section{DISCUSSION}

Cobalt and Ni soil amendments had a greater influence on foliar Co concentrations than on foliar Ni concentrations. For $\mathrm{Ni}$, phloem redistribution from young leaves to old leaves (which are the Ni sink in this tree species, Zelano et al. 2020) appeared to be operating on all three addition treatments regardless of the $\mathrm{Ni} / \mathrm{Co}$ quotient as the concentrations of $\mathrm{Ni}$ in old leaves were always higher than in young leaves and four times higher in the Ni750Co750 treatment. In contrast, Co translocation appeared to operate efficiently only for the Ni750Co750 treatment. For the Ni1500Co100 treatment, one could imagine that Ni was saturating the phloem, but in the Ni100Co1500 treatment the lack of Ni was also inhibiting Co translocation from young leaves to old leaves, although Co concentrations in soils and roots were much higher than for the other treatments. Another hypothesis is that Co is directly transferred to old leaves and young leaves by single xylem transport. The notable difference between $\mathrm{Co}$ and $\mathrm{Ni}$ is mainly explained by the significant increase of available Co in the soil after Co amendments as the soil used was initially poor in available $\mathrm{Co}$ whereas $\mathrm{Ni}$ amendments did not change as much the soil available Ni concentrations. In this Cambisol, Ni and Co are largely adsorbed onto the $\mathrm{Mn}$ and $\mathrm{Fe}$ hydrous oxide coatings on phyllosilicates (one of the dominant mineral 
phases being smectite clay minerals) and hence, remain highly available when dosed (Nkrumah et al. 2019c). The highest $\mathrm{Ni}$ concentrations along with a lesser Co enrichment in the old leaves of the Ni100Co1500 treatment may be explained by a severe physiological impairment that has affected $\mathrm{Ni}$ accumulation (greater phloem redistribution which probably induced the observed chlorosis for this treatment) and possibly many other physiological functions, including $\mathrm{P}$ metabolism and absorption or Mg/Mn uptake (Liu et al. 2000; Lopez-Moreno et al. 2016). It can be linked to the extreme concentrations of $\mathrm{Co}$ in the soil which translated in higher concentrations of $\mathrm{Co}$ in young leaves and non-foliar plant tissues. Comparatively, phytotoxicity occurred at $333 \mathrm{mg} \mathrm{kg}^{-1} \mathrm{~d}$.w. total Co in the soil for Berkheya coddii (Asteraceae), but no abnormal $\mathrm{Ni}$ uptake was observed in that study (Keeling et al. 2003). At lower Co phytoavailable concentrations in soils, Co accumulation and redistribution seems to be favoured to the detriment of $\mathrm{Ni}$ accumulation and redistribution. Antagonist interactions for $\mathrm{Ni}$ and Co uptake have been shown in Ni/Co hyperaccumulator plants (mostly in favour of Co uptake) as they compete for root metal transporters as well as intercellular ligands (Keeling et al. 2003; Lange et al. 2017; Tappero et al. 2007). In a much earlier study on the genus Odontarrhena (syn. Alyssum, Brassicaceae) in which Co and Ni uptake were tested in 'isomolar' supply of both metals, it was also concluded that Co suppresses Ni uptake (Homer et al. 1991). Cobalt may have a higher affinity for binding to the Ni transporters involved in root uptake and translocation to shoots as it is now observed in strong Ni hypernickelophores from different phylogenetic affinities. Further studies should focus on the biomolecular effects of $\mathrm{Ni}$ and $\mathrm{Co}$ competition in Ni hyperaccumulator plants. This could be the key mechanism accounting for facultative Co hyperaccumulation among Ni hyperaccumulator plants. In $R$. cf. bengalensis old leaves, Co was mostly located at the leaf margin and in numerous hotspots (exocellular sequestration) which indicates a different sequestration mechanism for Co and $\mathrm{Ni}$, the latter being stored around leaf epidermal cell walls mainly (van der Ent et al. 2017). Similar observations have been made for Odontarrhena chalcidica (synonym Alyssum murale) and Clethra barbinervis (Clethraceae), two other Co/Ni hyperaccumulator species (Tappero et al. 2007, Yamaguchi et al. 2019). The authors proposed that this elemental distribution is the consequence of the absence of any system or at least any transporter allowing Co to be concentrated significantly into vacuoles, this suggests that Co exposure was probably not an evolutionary driver in $R$. cf. bengalensis. This results in Co following the transpiration stream, which is more intense at the leaf margin (in the case of $O$. chalcidica, it is at the leaf tip) and eventually leads to the excretions of a precipitate that is rich in $\mathrm{Co}$ and $\mathrm{Ni}$ which is particularly visible via XFM on the leaf surface (Kabata-Pendias 2010). To date, the system allowing Ni to be transferred from the xylem to cell vacuoles remains unknown as the specific transport proteins needed are yet to be determined (van der Pas and Ingle 2019). Glochidion cf. sericeum, a Co/Ni hyperaccumulator from the Phyllanthaceae family and native to Sabah has a rather similar pattern, as Co is excreted on the surface of leaves in the form of lesions (van der Ent et al. 2018), similar to what is observed in leaves suffering from Mn toxicity (Blamey et al. 1986), and not dissimilar to $R$. cf. bengalensis as shown in this study.

The increasingly high demand for Co involving wider commercial applications has sparked the need to intensify the search for more Co ore deposits and to investigate Co recycling pathways. Phytomining has been intensively explored principally for $\mathrm{Ni}$, mainly because there are known 
suitable species (O. chalcidica, P. rufuschaneyi and $R$. cf. bengalensis) and substrates that can be used to achieve economically viable nickel yields from hyperaccumulator 'metal crops' (Bani et al. 2015; Li et al. 2003; Nkrumah et al. 2019b). Cobalt phytomining is potentially more profitable than $\mathrm{Ni}$ because of its higher value despite being volatile (in the last 5 years, $\mathrm{Ni}$ remained around $\$ 15 \mathrm{~kg}^{-1}$ while Co oscillated between $\left.\$ 30-90 \mathrm{~kg}^{-1}\right)$. Commercial operations of Co phytomining could potentially be developed on Co mineralised soils, soils contaminated with industrial Co emissions or waste disposal sites (Malik et al. 2000). However, accumulation of foliar Co to $>300 \mu \mathrm{g} \mathrm{g}^{-1} \mathrm{~d}$.w. is rare, and only 42 Co hyperaccumulator species (constituting just $\sim 5 \%$ of the total number of hyperaccumulator plant species) are known globally of which a majority is from the south-eastern part of the Democratic Republic of Congo growing on highly Co- enriched soils (Lange et al. 2017, Reeves et al. 2018). The highest foliar Co concentrations have been reported in $\mathrm{H}$. robertii from the Democratic Republic of Congo, with $1 \mathrm{Wt} \%$ (Brooks et al. 1977). Globally, extremely limited investigations have focussed on Co phytomining, and this study opens the possibility of exploring this technology in tropical regions using $R$. cf. bengalensis.

Appropriate agronomic systems need to be developed to optimise Co yields in this species. This would be critical for future economically viable and sustainable phytomining operations involving this species to start (Nkrumah et al. 2016; Nkrumah 2018). Further research is required to ascertain that $\mathrm{R}$. cf. bengalensis is of high potential for phytomining. Apart from the possible phytomining potential of $\mathrm{R}$. cf. bengalensis, this species remains an attractive model for studying the physiological mechanisms underlying polymetallic hyperaccumulation, especially in tropical woody plants.

\section{ACKNOWLEDGEMENTS}

This research was undertaken at P06 at the Deutsches Elektronen-Synchrotron, a member of the Helmholtz Association (HGF). We thank Jan Garrevoet for technical support during the experiment. We acknowledge the Laboratory of Excellence Ressources 21 for financial support. The research leading to this result has been supported by the project CALIPSOplus under the Grant Agreement 730872 from the EU Framework Programme for Research and Innovation HORIZON 2020. A. van der Ent was the recipient of a Discovery Early Career Researcher Award (DE160100429) from the Australian Research Council. A.L.D Paul is the recipient of an Australian Government Research Training Program Scholarship and UQ Centennial Scholarship at The University of Queensland, Australia.

\section{AUTHOR CONTRIBUTIONS}

A.L.D.P, P.N.N, G.E., S. S and A.vdE conducted the fieldwork and collected the samples in Malaysia. A.vdE, G.E. and K. S conducted the synchrotron X-ray Fluorescence Microscopy (XFM) experiment. AvdE performed the XFM data processing and analysis. All authors contributed to writing the manuscript. 


\section{REFERENCES}

Baker AJM, Brooks RR (1989) Terrestrial higher plants which hyperaccumulate metallic elements - a review of their distribution, ecology and phytochemistry. Biorecovery 1:81-126 Ballard HE, de Paula-Souza J, Wahlert GA (2014) Violaceae. In: Kubitzki K (ed) The families and genera of vascular plants.

Springer, Berlin, pp 303-322. https://doi.org/10.1007/978-3-642-39417-1_25

Bani A, Echevarria G, Sulçe S, Morel JL (2015) Improving the agronomy of Alyssum murale for extensive phytomining: a five-year field study. Int J Phytoremediat 17:117-127. https://doi.org/10.1080/15226514.2013.862204

Blamey FPC, Joyce DC, Edwards DG, Asher CJ (1986) Role of trichomes in sunflower tolerance to manganese toxicity. Plant Soil 91:171-180. https://doi.org/10.1007/BF02181785 Bouman R, van Welzen P, Sumail S, Echevarria G, Erskine PD, van der Ent A (2018) Phyllanthus rufuschaneyi: a new nickel hyperaccumulator from Sabah (Borneo Island) with potential for tropical phytomining. Bot Stud 59:9. https://doi. org/10.1186/s40529-018-0225-y Boyd RS (2007) The defense hypothesis of elemental hyperaccumulation: status, challenges and new directions. Plant Soil 293:153-176. https://doi.org/10.1007/s11104- 007-9240-6

Boyd RS, Martens SN (1992) The raison d'être for metal hyperaccumulation by plants. In: Baker AJM, Proctor J, Reeves RD (eds) The vegetation of ultramafic (serpentine) soils. Intercept Limited, Andover, pp 279-289

Brooks RR, Wither ED (1977) Nickel accumulation by Rinorea bengalensis (Wall.) O.K. J Geochem Explor 7:295-300. https://doi.org/10.1016/0375-6742(77)90085-1

Brooks RR, Lee J, Reeves RD, Jaffré T (1977) Detection of nickeliferous rocks by analysis of herbarium specimens of indicator plants. J Geochem Explor 7:49-57. https://doi. org/10.1016/0375-6742(77)90074-7

Chaney RL, Reeves RD, Baklanov IA, Centofanti T, Broadhurst CL, Baker AJM, Angle JS, van der Ent A, Roseberg RJ (2014) Phytoremediation and phytomining: using plants to remediate contaminated or mineralized environments, chap.

15. In: Rajakaruna N, Boyd RS, Harris T (eds) Plant ecology and evolution in harsh environments. Nova Science, New York, pp 365-391

Chen C, Huang D, Liu J (2009) Functions and toxicity of nickel in plants: recent advances and future prospects. Clean 37:304- 313. https://doi.org/10.1002/clen.200800199

De Hertogh AA, Mayeux PA, Evans HJ (1964) The relationship of cobalt requirement to propionate metabolism in rhizobium. J Biol Chem 239:2446-2453

Dixon NE, Gazzola TC, Blakeley RL, Zermer B (1975) Jack bean urease (EC 3.5.1.5). A metalloenzyme. A simple biological role for nickel? J Am Chem Soc 97(14):4131-4133

Guillot S, Hattori K (2013) Serpentinites: essential roles in geodynamics, arc volcanism, sustainable development, and the origin of life. Elements 9:95-98. https://doi.org/10.2113

/gselements.9.2.95

Homer FA, Morrison RS, Brooks RR, Clemens J, Reeves RD (1991) Comparative-studies of nickel, cobalt, and copper uptake by some nickel hyperaccumulators of the genus Alyssum. Plant Soil 138:195-205

Hörger AC, Fones HN, Preston GM (2013) The current status of the elemental defense hypothesis in relation to pathogens. Front Plant Sci 4 :395 . https://doi.org/10.3389

/fpls.2013.00395 
Jones MWM, Kopittke PM, Casey LW, Reinhardt J, Pax F, Blamey C, van der Ent A (2020) Assessing radiation dose limits for X-ray fluorescence microscopy analysis of plant specimens. Ann Bot 125:599-610. https://doi.org/10.1093/aob/mcz195

Kabata-Pendias A (2010) Trace elements in soils and plants. CRC Press/Taylor \& Francis Group 4th edition, Boca Raton

Kabeya FI, Pongrac P, Lange B, Faucon MP, Van Elteren JT, Šala M, Šelih VS, Eeckhoudt EV, Verbruggen N (2018) Tolerance and accumulation of cobalt in three species of Haumaniastrum and the influence of copper. Environ Exp B o t 149:27 - 33 . https://doi.org/10.1016/j. envexpbot.2018.01.018

Keeling SM, Stewart RB, Anderson CW, Robinson BH (2003) Nickel and cobalt phytoextraction by the hyperaccumulator Berkheya coddii: implications for polymetallic phytomining and phytoremediation. Int $J$ Phytoremediation 5:235-244. https://doi.org/10.1080/713779223

Kirkham R, Dunn PA, Kucziewski A, Siddons DP, Dodanwela R, Moorhead G, Ryan CG, De Geronimo G, Beuttenmuller R, Pinelli D, Pfeffer M, Davey P, Jensen M, Paterson D, de Jonge MD, Kusel M, McKinlay J (2010) The Maia spectros- copy detector system: engineering for integrated pulse cap- ture, low-latency scanning and real-time processing. AIP Conf Proc 1234:240-243. https://doi.org/10.1063/1.3463181

Küpper H, Lombi E, Zhao FJ, Wieshammer G, McGrath SP (2001) Cellular compartmentation of nickel in the hyperaccumulators Alyssum lesbiacum, Alyssum bertolonii and Thlaspi goesingense. J Exp Bot 52:2291-2300. https://doi.org/10.1093/jexbot/52.365.2291

Lange B, van der Ent A, Baker AJ, Echevarria G, Mahy G, Malaisse F, Meerts P, Pourret O, Verbruggen N, Faucon MP (2017) Copper and cobalt accumulation in plants: a critical assessment of the current state of knowledge. New Phytol 213:537-551. https://doi.org/10.1111/nph.14175

Li YM, Chaney R, Brewer E, Roseberg R, Angle JS, Baker AJM, Reeves R, Nelkin J (2003) Development of a technology for commercial phytoextraction of nickel: economic and technical considerations. Plant Soil 249:107-115. https://doi. org/10.1023/A:1022527330401

Liu J, Reid RJ, Smith FA (2000) The mechanism of cobalt toxicity in mung beans. Physiol Plant 110:104-110. https://doi. org/10.1034/j.1399-3054.2000.110114.x

Lopez-Moreno ML, Aviles LL, Perez NG, Irizarry BT, Perales O, Cedeno-Mattei Y, Roman F (2016) Effect of cobalt-ferrite nanoparticles on the growth and development of Solanum lycopersicum L. (tomato plants). Sci Total Environ 550:45- 52. https://doi.org/10.1016/j.scitotenv.2016.01.063

Malik M, Chaney RL, Brewer EP, Angle JS (2000) Phytoextraction of soil cobalt using hyperaccumulator plants. Int J Phytorem 2:319-329. https://doi.org/10.1080 /15226510008500041

Morrissey J, Baxter IR, Lee J, Li L, Lahner B, Grotz N, Kaplan J, Salt DE, Guerinot ML (2009) The ferroportin metal efflux proteins function in iron and cobalt homeostasis in Arabidopsis. Plant Cell 21:3326-3338. https://doi. org/10.1105/tpc.109.069401

Nkrumah P (2018) Hyperaccumulation of trace elements in native species from Sabah (Malaysia): new discoveries and practical considerations for viable tropical nickel agromining, $\mathrm{PhD}$ Thesis, Sustainable Minerals Institute, The University of Queensland 
Nkrumah PN, Baker AJM, Chaney RL, Erskine PD, Echevarria G, Morel JL, van der Ent A (2016) Current status and challenges in developing nickel phytomining: an agronomic perspective. Plant Soil 406:55-69. https://doi.org/10.1007/s11104-016- 2859-4

Nkrumah P, Echevarria G, Erskine PD, van der Ent A (2018a) Contrasting nickel and zinc hyperaccumulation in subspecies of Dichapetalum gelonioides from Southeast Asia. Sci Rep 8: 9659. https://doi.org/10.1038/s41598-018-26859-7

Nkrumah PN, Echevarria G, Erskine PD, van der Ent A (2018b) Nickel hyperaccumulation in Antidesma montis-silam: from herbarium discovery to collection in the native habitat. Ecol Res 33:675-685. https://doi.org/10.1007/s11284-018-1601-5

Nkrumah PN, Echevarria G, Erskine PD, Chaney RL, Sumail S, van der Ent A (2019a) Soil amendments affecting nickel uptake and growth performance of tropical 'metal crops' used for agromining. J Geochem Explor 203:78-86. https://doi. org/10.1016/j.gexplo.2019.03.009

Nkrumah PN, Echevarria G, Erskine PD, Chaney RL, Sumail S, van der Ent A (2019b) Growth effects in tropical nickel- agromining 'metal crops' in response to nutrient dosing. J Plant Nutr Soil Sci 182:715-728. https://doi.org/10.1002

/jpln.201800468

Nkrumah PN, Echevarria G, Erskine PD, Chaney RL, Sumail S, van der Ent A (2019c) Effect of nickel concentration and soil $\mathrm{pH}$ on metal accumulation and growth in tropical agromining 'metal crops'. Plant Soil 443:27-39. https://doi.org/10.1007/s11104-019-04200-z

Oven M, Grill E, Golan-Goldhirsh A, Kutchan TM, Zenk MH (2002) Increase of free cysteine and citric acid in plant cells exposed to cobalt ions. Phytochem 60:467-474. https://doi. org/10.1016/S0031-9422(02)00135-8

Proctor J (2003) Vegetation and soil and plant chemistry on ultramafic rocks in the tropical Far East. Perspect Plant Ecol Evol Syst 6:105-124. https://doi.org/10.1078/1433- 8319-00045

Reeves RD, Baker AJM, Jaffré T, Erskine PD, Echevarria G, van der Ent A (2018) A global database for plants that hyperaccumulate metal and metalloid trace elements. New Phytol 218:407-411. https://doi.org/10.1111/nph.14907

Ryan CG (2000) Quantitative trace element imaging using PIXE and the nuclear microprobe. Int J Imag Syst Tech 11:219-230. https://doi.org/10.1002/ima.1007

Ryan CG, Jamieson DN (1993) Dynamic analysis: on-line quan- titative PIXE microanalysis and its use in overlap-resolved elemental mapping. Nucl Instrum Meth B 77:203-214. https://doi.org/10.1016/0168-583X(93)95545-G

Ryan CG, Cousens D, Sie S, Griffin W (1990) Quantitative analysis of PIXE spectra in geoscience applications. Nucl Instrum Meth B 49:271-276. https://doi.org/10.1016/0168583X(90)90259-W

Ryan CG, Etschmann BE, Vogt S, Maser J, Harland CL, van Achterbergh E, Legnini D (2005) Nuclear microprobe- synchrotron synergy: towards integrated quantitative real- time elemental imaging using PIXE and SXRF. Nucl Instrum Meth B 231:183-188. https://doi.org/10.1016/j. nimb.2005.01.054

Ryan CG, Kirkham R, Hough RM, Moorhead G, Siddons DP, De Jonge MD, Paterson DJ, De Geronimo G, Howard DL, Cleverley JS (2010) Elemental X-ray imaging using the Maia detector array: the benefits and challenges of large solid-angle. Nucl Instrum Meth A 619:3743. https://doi. org/10.1016/j.nima.2009.11.035 
Ryan CG, Siddons DP, Kirkham R, Li ZY, de Jonge MD, Paterson DJ, Kuczewski A, Howard DL, Dunn PA, Falkenberg G, Boesenberg U, De Geronimo G, Fisher LA, Halfpenny A, Lintern MJ, Lombi E, Dyl KA, Jensen M, Moorhead GF, Cleverley JS, Hough RM, Godel B, Barnes SJ, James SA, Spiers KM, Alfeld M, Wellenreuther G, Vukmanovic Z, Borg S (2014) Maia Xray fluorescence imaging: capturing detail in complex natural samples. X-ray optics and microanalysis. J Phys Conf Ser 499:012002. https://doi. org/10.1088/1742-6596/499/1/012002 Schroer CG, Boye P, Feldkamp JM, Patommel J, Samberg D, Schropp A, Schwab A, Stephan S, Falkenberg G, Wellenreuther G, Reimers N (2010) Hard X-ray nanoprobe at beamline P06 at PETRA III. Nucl Instrum Meth A 616:93-97. https://doi.org/10.1063/1.4952830

Siddons DP, Kirkham R, Ryan CG, De Geronimo G, Dragone A, Kuczewski AJ, Li ZY, Carini GA, Pinelli D, Beuttenmuller R, Elliott D, Pfeffer M, Tyson TA, Moorhead GF, Dunn PA (2014) Maia X-ray microprobe detector Array system. J Phys Conf Ser 499:012001-012010. https://doi.org/10.1088/1742-6596/499/1/012001

Tappero R, Peltier E, Gräfe M, Heidel K, Ginder-Vogel M, Livi KJT, Rivers ML, Marcus MA, Chaney RL, Sparks DL (2007) Hyperaccumulator Alyssum murale relies on a differ- ent metal storage mechanism for cobalt than for nickel. New Phytol 175:641-654. https://doi.org/10.1111/j.1469- 8137.2007.02134.x

van der Ent A, Mulligan D (2015) Multi-element concentrations in plant parts and fluids of Malaysian nickel hyperaccumulator plants and some economic and ecological considerations. J Chem Ecol 41:396-408. https://doi.org/10.1007/s10886- 015-0573-y

van der Ent A, Baker AJM, Reeves RD, Pollard AJ, Schat H (2013) Hyperaccumulators of metal and metalloid trace ele- ments: facts and fiction. Plant Soil 362:319-334. https://doi. org/10.1007/s11104-012-1287-3

van der Ent A, Jaffré T, L'Huillier L, Gibson N, Reeves RD (2015a) The flora of ultramafic soils in the Australia-Pacific region: state of knowledge and research priorities. Aust J Bot 63:173-190. https://doi.org/10.1071/BT15038

van der Ent A, Erskine PD, Sumail S (2015b) Ecology of nickel hyperaccumulator plants from ultramafic soils in Sabah (Malaysia). Chemoecol 25:243-259. https://doi.org/10.1007

/s00049-015-0192-7

van der Ent A, Baker AJM, Reeves RD, Chaney RL, Anderson CWN, Meech JA, Erskine PD, Simonnot MO, Vaughan J, Morel JL, Echevarria G, Fogliani B, Qiu RL, Mulligan DR (2015c) Agromining: farming for metals in the future? Environ Sci Technol 49:4773-4780. https://doi.org/10.1021/es506031u

van der Ent A, van Balgooy MMJ, van Welzen P (2016) Actephila alanbakeri (Phyllanthaceae): a new nickel hyperaccumulating species from localised ultramafic soils in Sabah (Malaysia). Bot Stud 57:6. https://doi.org/10.1186/s40529-016-0122-1

van der Ent A, Callahan DL, Noller BN, Mesjasz-Przybylowicz J, Przybylowicz WJ, Barnabas A, Harris HH (2017) Nickel biopathways in tropical nickel hyperaccumulating trees from Sabah (Malaysia). Sci Rep 7:41861. https://doi.org/10.1038/srep41861

van der Ent A, Mak R, de Jonge MD, Harris HH (2018) Simultaneous hyperaccumulation of nickel and cobalt in the tree Glochidion cf. sericeum (Phyllanthaceae): elemental dis- tribution and chemical speciation. Sci Rep 8:9683. https://doi.org/10.1038/s41598-018-26891-7

van der Ent A, Erskine PD, Malaisse F, Mesjasz-Przybylowicz J, Przybylowicz WJ, Barnabas AD, Sosnicka M, Harris HH (2019) Abnormal concentrations of Cu-Co in Haumaniastrum 
katangense, Haumaniastrum robertii and Aeolanthus biformifolius: contamination or hyperaccumulation?

Metallomics 11:586-596. https://doi.org/10.1039/c8mt00300a van der Ent A, de Jonge MD, Mak R, Mesjasz-Przybylowicz J, Przybylowicz WJ, Barnabas AD, Harris HH (2020a) X-ray fluorescence elemental mapping of roots, stems and leaves of the nickel hyperaccumulators Rinorea cf. bengalensis and Rinorea cf. javanica (Violaceae) from Sabah (Malaysia), Borneo. Plant Soil 448:15-36. https://doi.org/10.1007/s11104-019-04386-2

van der Ent A, Erskine PD, Vinya R, Malaisse F, Mesjasz- Przybylowicz J, Przybylowicz WJ, Barnabas AD, Harris HH (2020b) Elemental distribution and chemical speciation of copper and cobalt in three metallophytes from Zambia. Metallomics in press

van der Pas L, Ingle RA (2019) Towards an understanding of the molecular basis of nickel hyperaccumulation in plants. Plants 8:11. https://doi.org/10.3390/plants8010011

Wahlert GA, Ballard HE (2012) A phylogeny of Rinorea (Violaceae) inferred from plastid DNA sequences with an emphasis on the African and Malagasy species. Syst Bot 37: 964-973. https://doi.org/10.1600/036364412X656392

Yamaguchi T, Tsukada C, Takahama K, Hirotomo T, Tomioka R, Takenaka C (2019) Localization and speciation of cobalt and nickel in the leaves of the cobalt-hyperaccumulating tree Clethra barbinervis. Trees 33:521-532. https://doi. org/10.1007/s00468-018-1797-6

Zelano I, Cloquet C, van der Ent A, Echevarria G, Gley R, Landrot G, Pollastri S, Fraysse F, Montargès-Pelletier E (2020) Coupling nickel chemical speciation and isotope ratios to decipher nickel dynamics in the Rinorea cf. bengalensis-soil system in Malaysian Borneo. Plant Soil, in press. https://doi. org/10.1007/s11104-020-04541-0 
Table 1. Chemical concentrations of major and trace elements in the ultramafic soil with a $\mathrm{pH}$ of 6.03 collected in the vicinity of Pahu(Sabah, Malaysia) used in the experiment.

\begin{tabular}{|c|c|c|c|c|c|}
\hline Extraction method & Ca & Fe & K & Mg & P \\
\hline Pseudo-total $\left(\mathrm{g} \mathrm{kg}^{-1}\right)$ & 5.38 & 188 & 0.37 & 64.7 & 0.24 \\
\hline $\mathrm{CEC}\left(\mathrm{cmol}^{+} \mathrm{kg}^{-1}\right)$ & 4.90 & - & 0.30 & 17.8 & - \\
\hline
\end{tabular}

\begin{tabular}{|c|c|c|c|c|c|}
\hline Extraction method & Co & Cr & Mn & Ni & Zn \\
\hline Pseudo-total $\left(\mathrm{mg} \mathrm{kg}^{-1}\right)$ & 445 & 7610 & 3590 & 4730 & 155 \\
\hline DTPA $\left(\mathrm{mg} \mathrm{kg}^{-1}\right)$ & 20.0 & 0.65 & 560 & 280 & 5.05 \\
\hline $\mathrm{Sr}\left(\mathrm{NO}_{3}\right)_{2}\left(\mathrm{mg} \mathrm{kg}^{-1}\right)$ & 0.30 & 0.05 & 15.0 & 7.00 & 0.20 \\
\hline
\end{tabular}



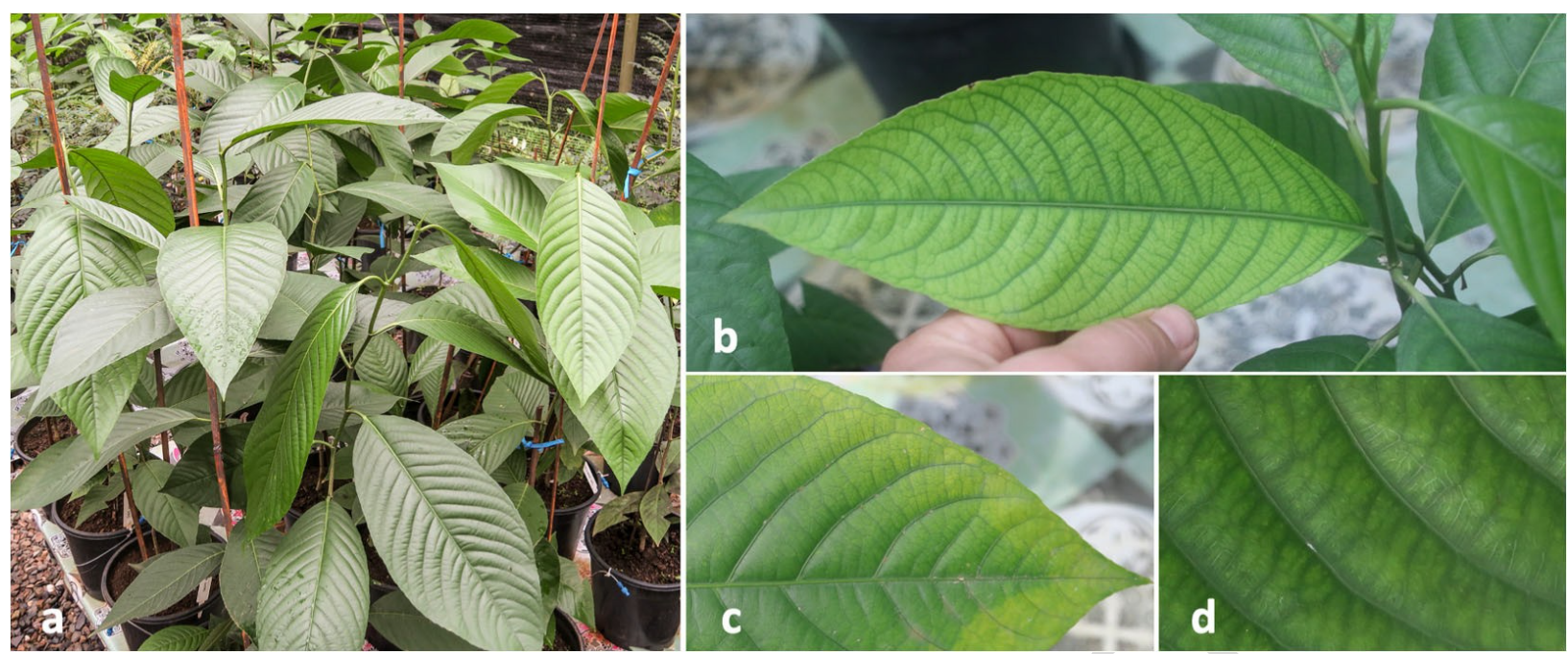

Fig. 1 Visual appearance of Rinorea $\mathrm{cf}$. bengalensis at harvest (a) and three different close-ups of the leaf yellowing observed in the Ni100Co1500 treatment at the conclusion of the $\mathrm{Ni} / \mathrm{Co}$ dosing experiment $(b, c, d)$. 


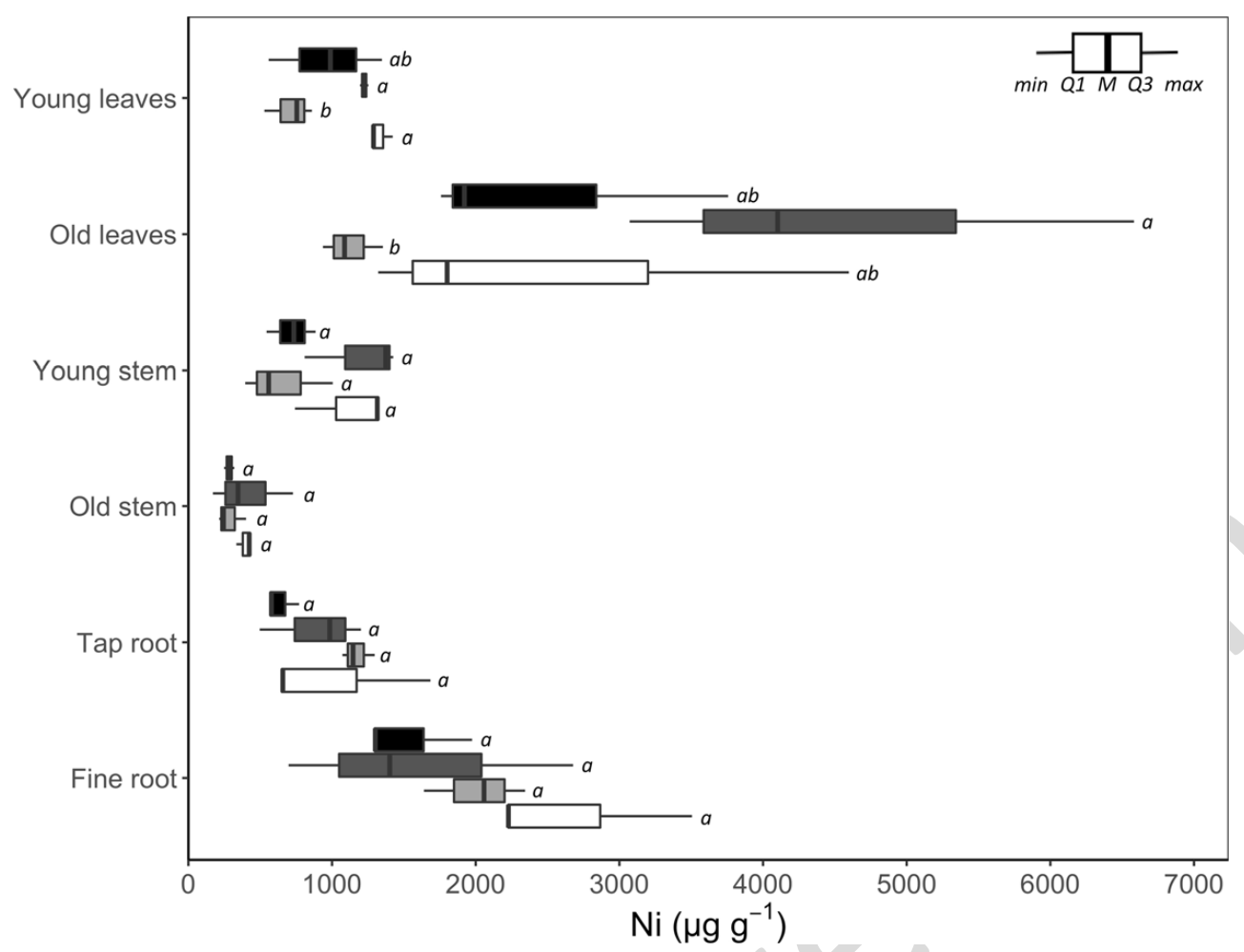

Fig. 2 Concentrations of $\mathrm{Ni}$ (dry weight) in various plant parts of Rinorea cf. bengalensis according to treatments (Black: Control, Dark grey: Ni100Co1500, Light grey: Ni750Co750, White: Ni1500Co100). For each variable, the affected modalities of the same letter are not significantly different (Waller-Duncan means separation test, $\mathrm{p}<0.05$ ). Box-whisker plots depict data through five values: sample minimum (min), lower quartile (Q1), median (M), upper quartile (Q3) and maximum (max). 


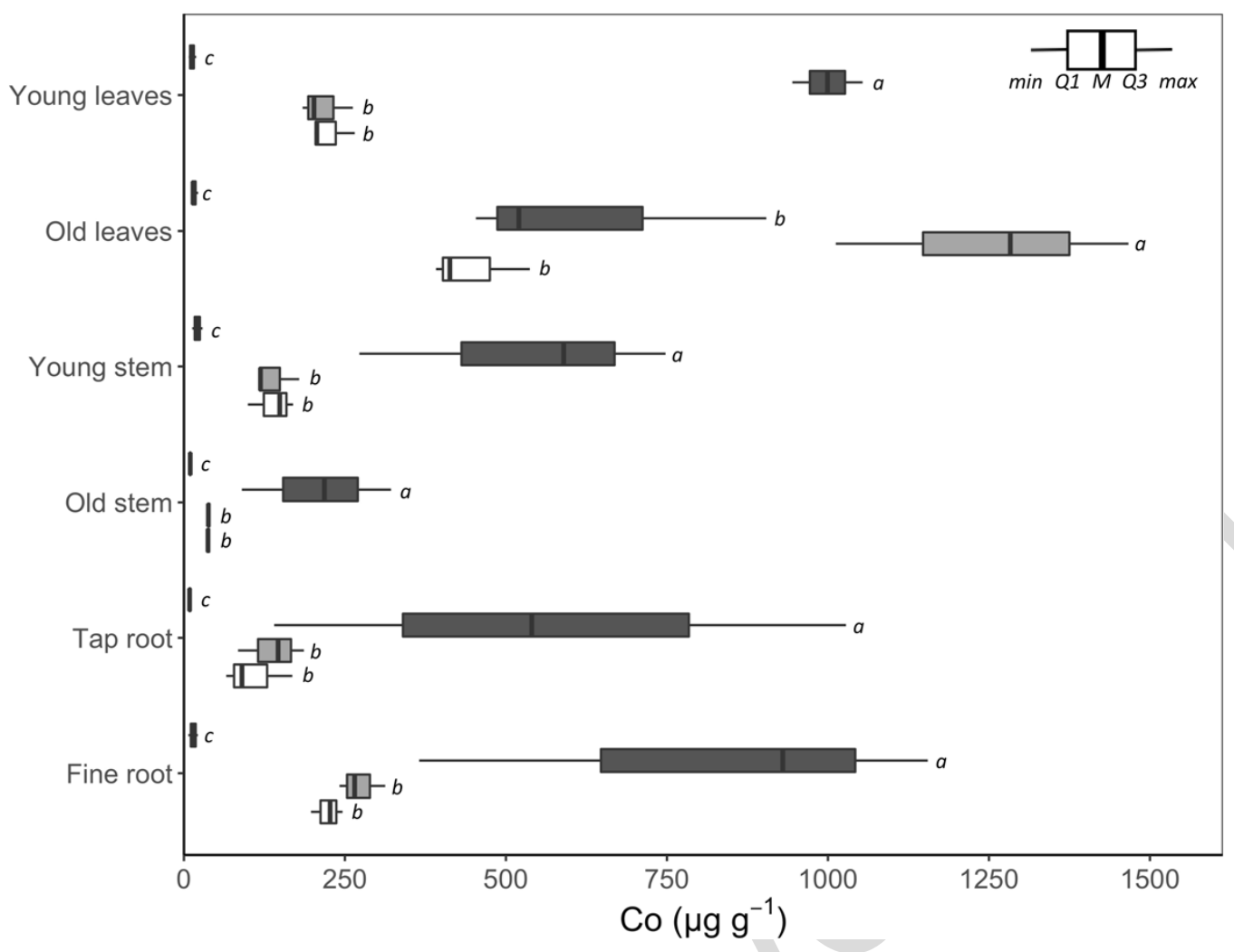

Fig. 3 Concentrations of Co (dry weight) in various plant parts of Rinorea $\mathrm{cf}$. bengalensis according to treatments (Black: Control, Dark grey: Ni100Co1500, Light grey: Ni750Co750, White: Ni1500Co100). For each variable, the affected modalities of the same letter are not significantly different (Waller- Duncan means separation test, $\mathrm{p}<0.05$ ). Box-whisker plots depict data through five values: sample minimum (min), lower quartile (Q1), median (M), upper quartile (Q3) and maximum (max). 

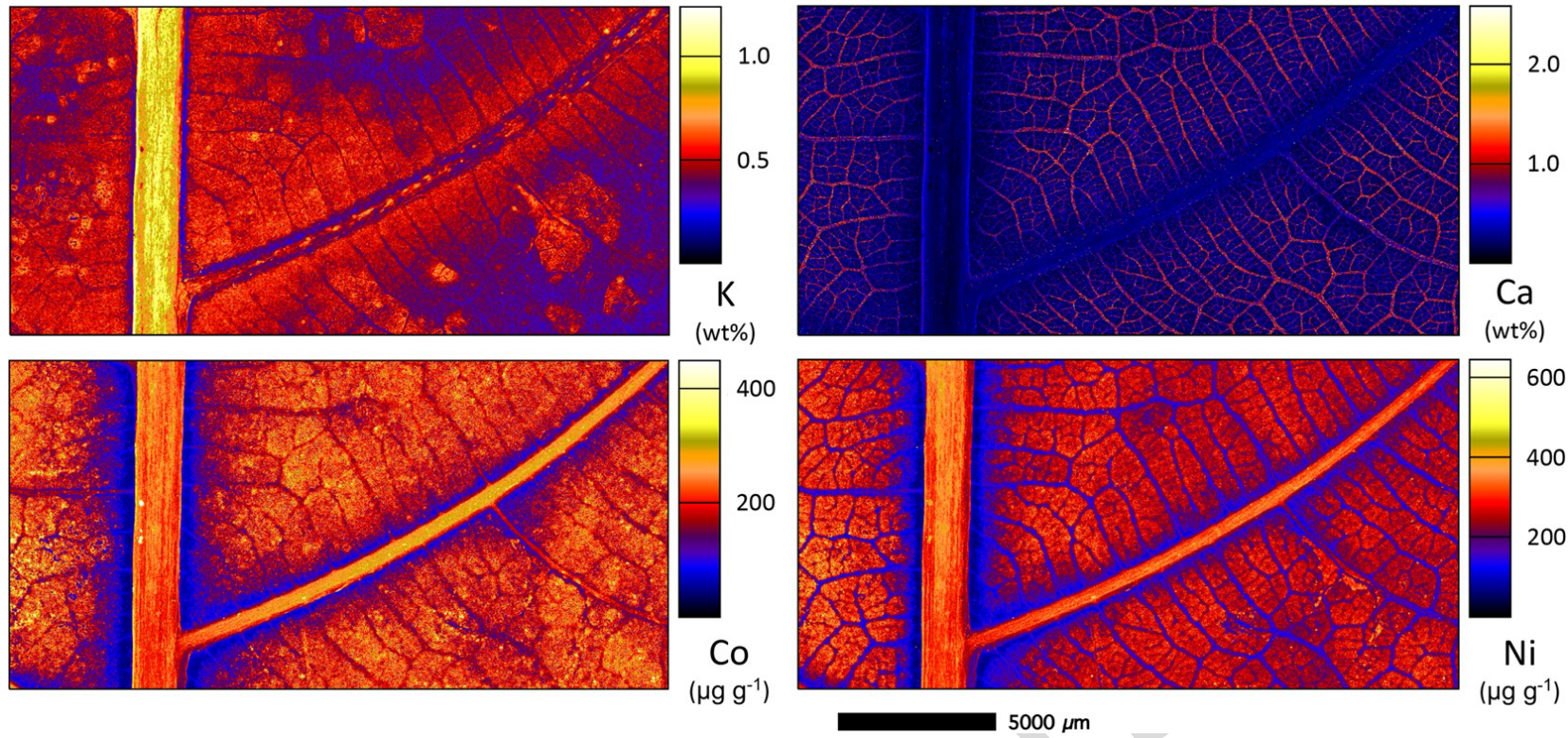

Fig. 4 Synchrotron $\mu \mathrm{XRF}$ maps $(\mathrm{Ca}, \mathrm{Co}, \mathrm{K}$ and $\mathrm{Ni}$ ) of a fresh leaf portion of a Rinorea $\mathrm{cf}$. bengalensis young leaf. 

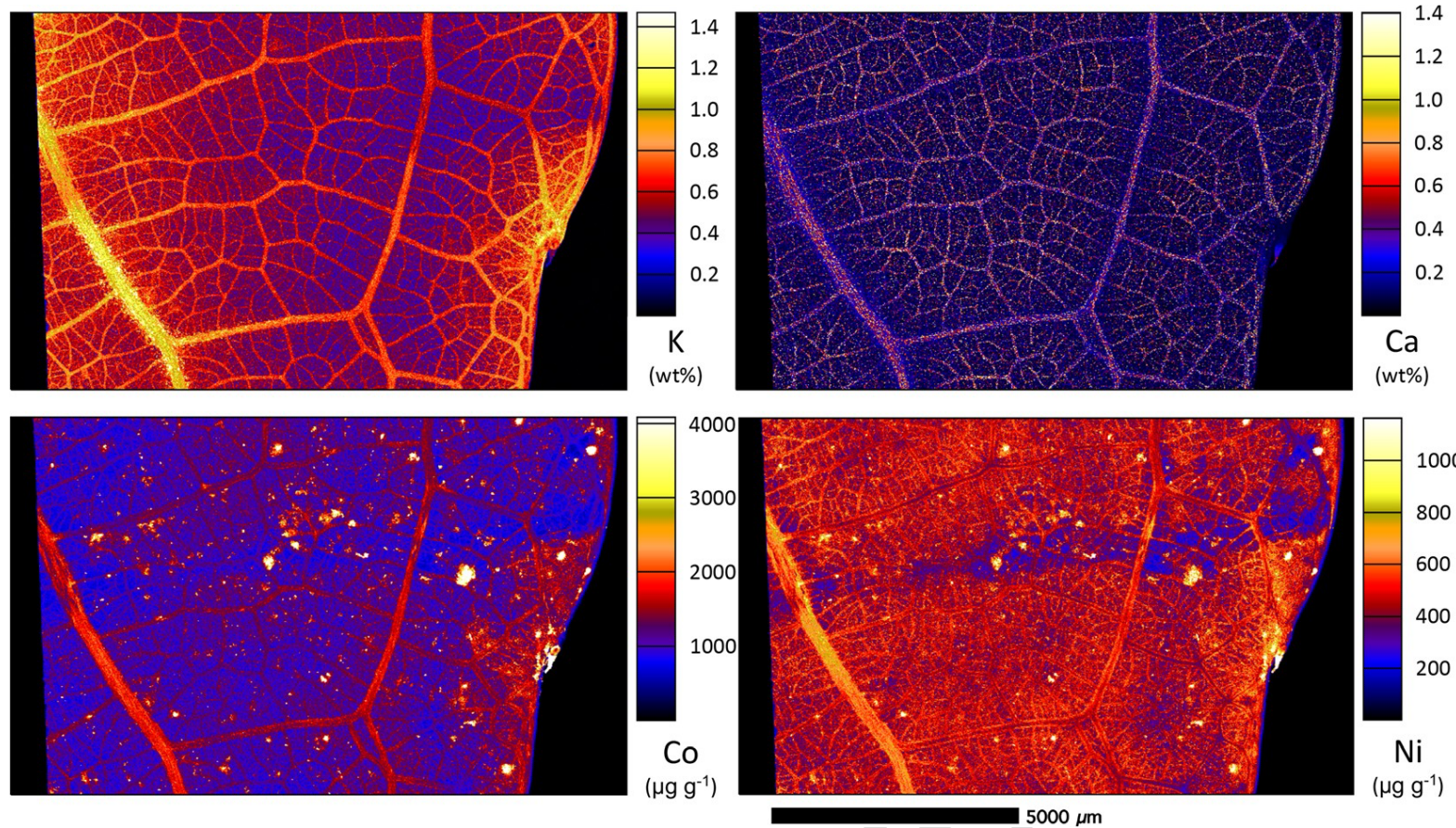

Fig. 5 Synchrotron $\mu \mathrm{XRF}$ maps $(\mathrm{Ca}, \mathrm{Co}, \mathrm{K}$ and $\mathrm{Ni}$ ) of a fresh leaf portion of a Rinorea $\mathrm{cf}$. bengalensis old leaf. 

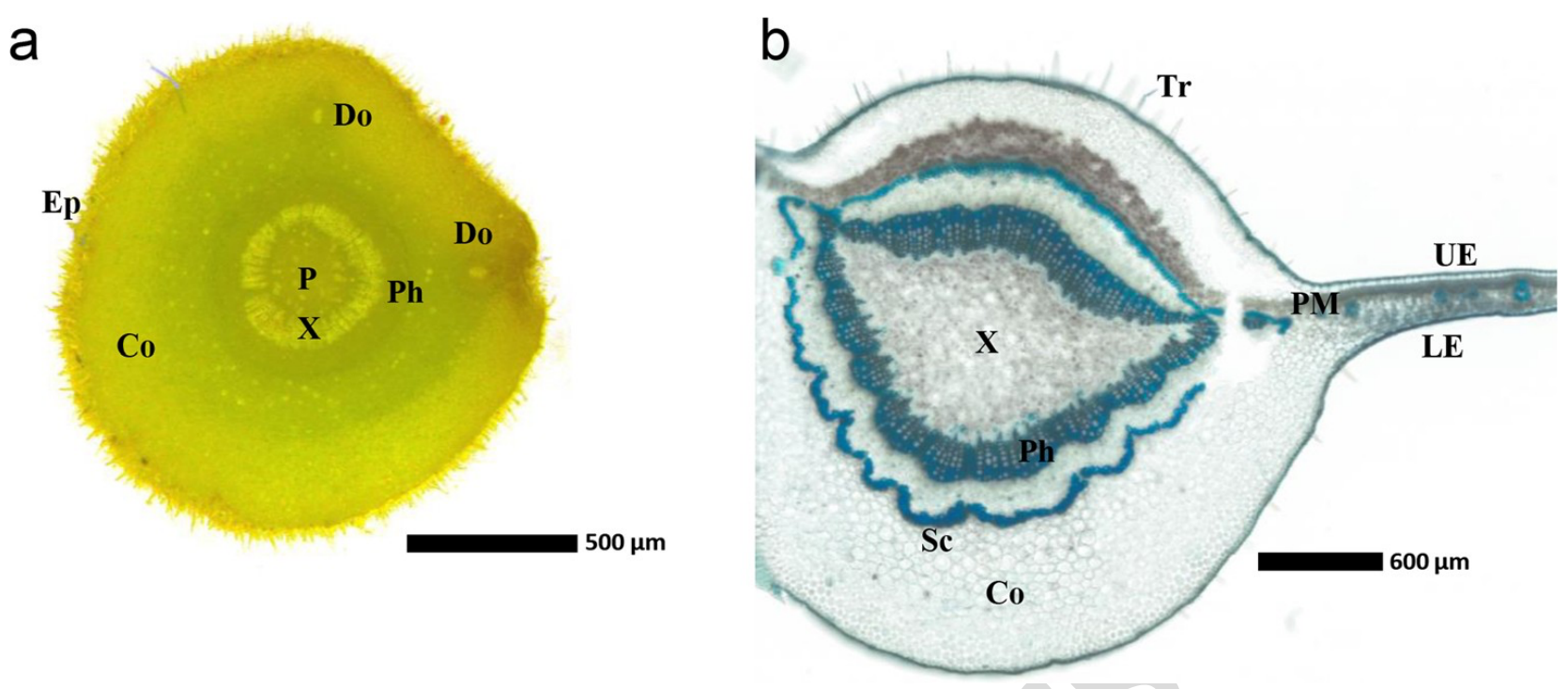

Fig. 6 Light microscopy images of toluidine-stained and non-stained cross-sections of petiole (a) and leaf (b) of Rinorea cf. bengalensis. Abbreviations annotated of anatomical features: Co cortex, Do Domatia, Ep epidermis, LE lower epidermis, $\mathrm{P}$ pith, Ph phloem, PM palisade mesophyll, Sc sclerenchyma, Tr Trichome, UE upper epidermis, X xylem. 

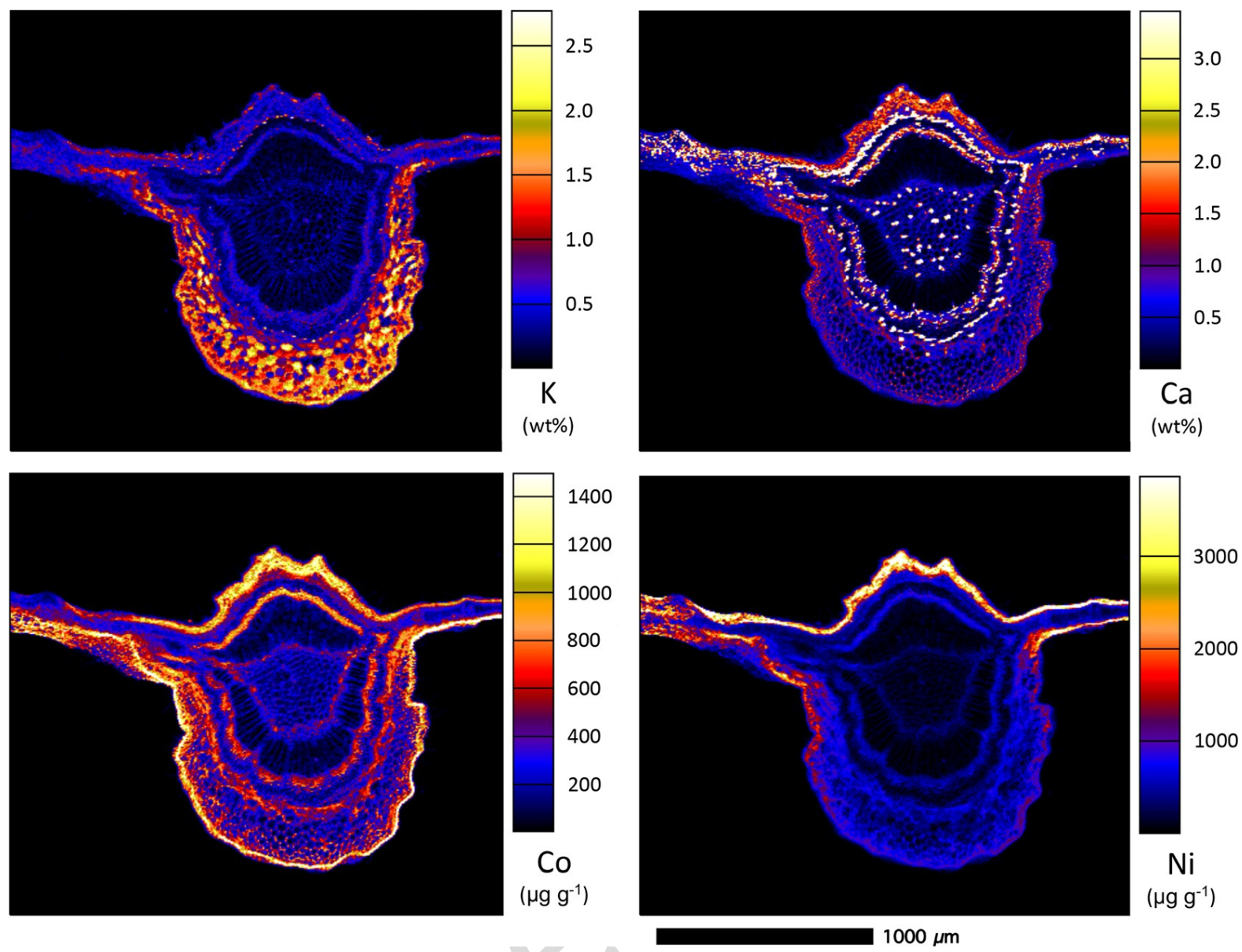

Fig. 7 Synchrotron $\mu \mathrm{XRF}$ maps (Ca, Co, K and Ni) of a Rinorea $\mathrm{cf}$. bengalensis old leaf midrib. 

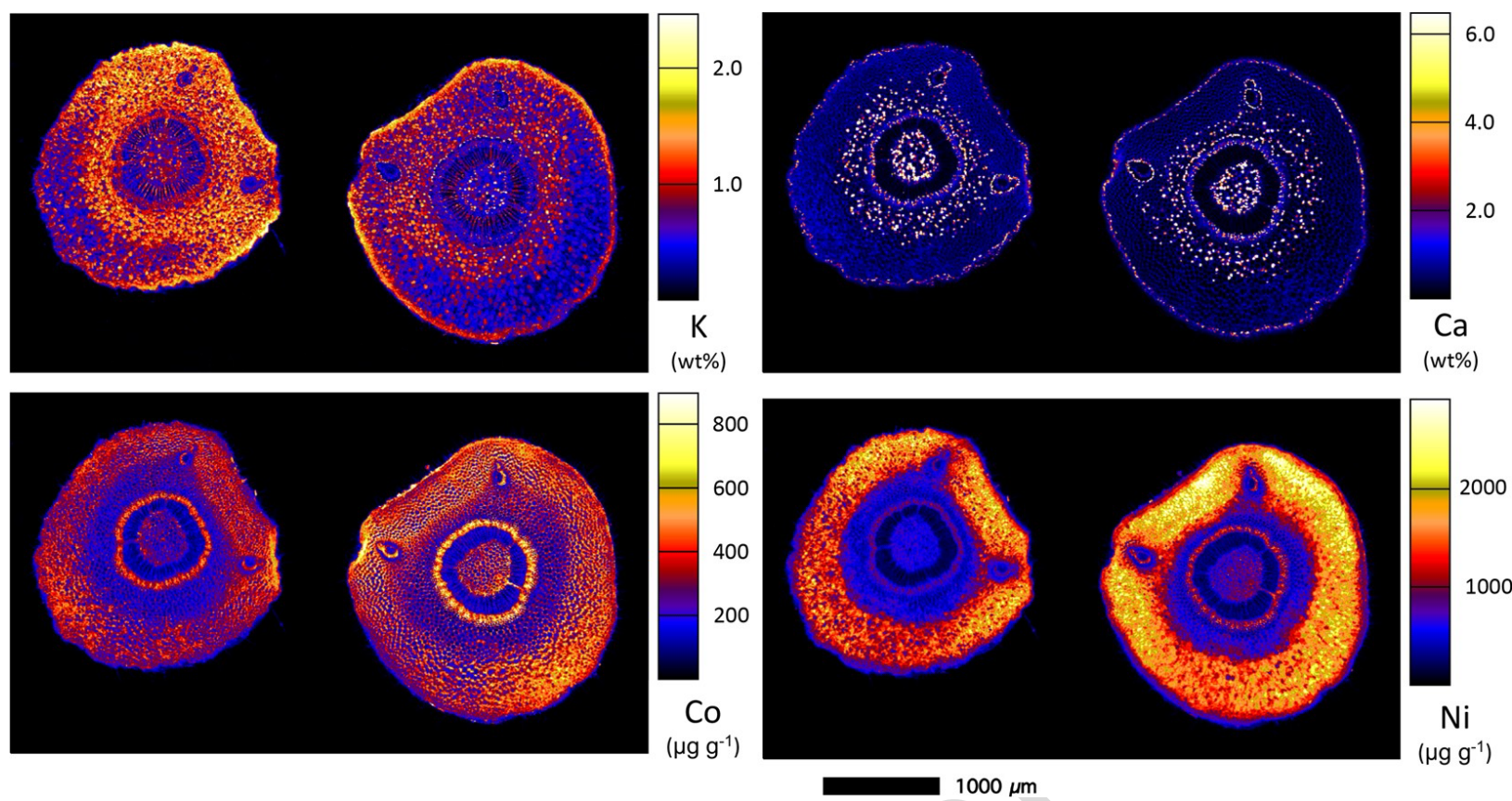

Fig. 8 Synchrotron $\mu$ XRF maps ( $\mathrm{Ca}, \mathrm{Co}, \mathrm{K}$ and Ni) of a Rinorea $\mathrm{cf}$. bengalensis old leaf petiole. 

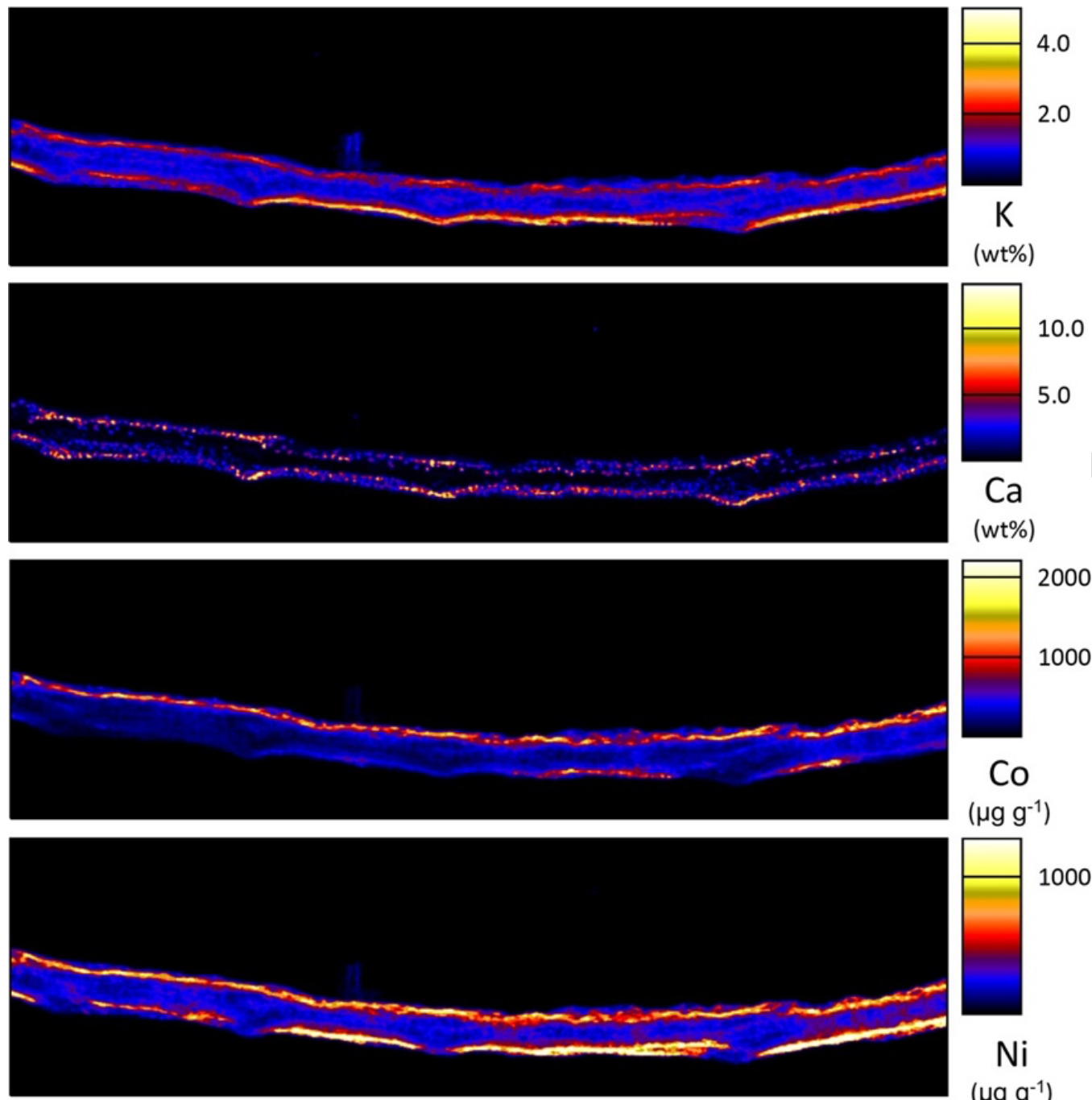

$\left(\mu \mathrm{g} \mathrm{g}^{-1}\right)$

Fig. 9 Synchrotron $\mu \mathrm{XRF}$ maps $(\mathrm{Ca}, \mathrm{Co}, \mathrm{K}$ and $\mathrm{Ni})$ of a Rinorea $\mathrm{cf}$. bengalensis old leaf crosssection. 